\title{
Czy ustawa jest dobra na wszystko?
}

Stwierdzenie, że rzymskie państwo zmagało się z wieloma patologiami, to truizm. Na pytanie, czy ustawa jest dobra na wszystko, prawie każdy też bez głębszego zastanowienia odpowie przecząco. Ciekawe może być jednak bliższe przyjrzenie się temu problemowi na podstawie konkretnych przykładów zaczerpniętych głównie $\mathrm{z}$ historii prawa rzymskiej republiki. Patologie, na które, w kontekście postawionego w tytule pytania, warto zwrócić uwagę, to lichwiarstwo i jego konsekwencje, rozrzutność i nieumiarkowanie w jedzeniu i piciu, w pewnej mierze związane z korupcją polityczną; wreszcie - dotykająca wszystkie warstwy społeczne plaga gier losowych. Oczywiście lista jest niekompletna, można tu na przykład dodać choćby prostytucję i stręczycielstwo czy kontrabandę, ale nawet powierzchowny przegląd wymienionych w pierwszej kolejności zagadnień może stanowić ciekawy przyczynek do refleksji na temat skuteczności ingerencji państwa.

Lektura pierwszych ksiąg Ab Urbe condita Liwiusza pokazuje dość jasno, że najwięcej emocji w życiu społecznym wywoływały dwa palące problemy: ziemia i długi. Walka o władzę, w szczególności walka plebejuszy o dostęp do urzędów, jest tu wtórnym problemem. Wtórnym o tyle, że z rzeczywistą ostrością ujawnił się on dopiero z czasem, gdy interesy polityczne wyższych warstw plebejuszy były już z gruntu odmienne od tych prezentowanych przez doły społeczne'.

W Rzymie pojawiło się zjawisko masowego zadłużenia niższych warstw społecznych. Wprawdzie rzymska pożyczka (mutuum) została skonstruowana

${ }^{1}$ Jeszcze pod rokiem 357 p.n.e. Liwiusz (Liv. 6, 34-35) mówi wyraźnie, że wobec przygniatającego zadłużenia lud był mało zainteresowany życiem politycznym, ożywienie nastąpiło dopiero po przeprowadzeniu oddłużenia — władza uzyskała poparcie, o które zabiegała. 
jako instytucja nieodpłatna ${ }^{2}$, to standardowo dodawana do kontraktu stypulacja odsetkowa uczyniła z pożyczki dogodne źródło dochodów dla każdego, kto, choćby czasowo, dysponował wolnymi środkami. Jeśli dodać do tego, że rzymska pożyczka miała na ogół charakter konsumpcyjny — była brana na zaspokojenie codziennych potrzeb, spłatę innych, wcześniej zaciągniętych pożyczek, wreszcie zapłacenie podatków ${ }^{3}$ - niemal nieuchronnie musiała prowadzić do ruiny dłużnika. Sytuację pogarszała jeszcze pierwotna swoboda w określaniu stopy odsetek umownych ${ }^{4}$, powszechna praktyka doliczania do kapitału podstawowego odsetek niezapłaconych w terminie, tak że same one dawały odsetki (anatocyzm) ${ }^{5}$ i surowość egzekucji w razie niewypłacalności dłużnika ${ }^{6}$. To nieinwestycyjne przeznaczenie środków powodowało stałe narastanie zadłużenia. W całym okresie republikańskim, ale przede wszystkim w dwóch pierwszych wiekach republiki, kiedy podziały polityczne przekładały się wprost na rozwarstwienie majątkowe, był to jeden z podstawowych problemów, z jakimi musiała poradzić sobie patrycjuszowska władza. Kiedy bowiem stan ogólnego zadłużenia osiągał poziom krytyczny, wywołane tym faktem rozruchy godziły w stabilność państwa - zarówno w spokój wewnętrzny, jak i w bezpieczeństwo zewnętrzne. Traciły one nieco na ostrości jedynie w obliczu zagrożenia zewnętrznego ${ }^{7}$, choć warto tu zwrócić uwagę, że wcielony do legionów, a więc oderwany od pracy drobny rolnik, przynajmniej do czasu wprowadzenia żołdu (stipendium) ${ }^{8}$, musiał łatwo wpadać w spiralę zadłużenia. Sytuacja była więc dynamiczna, a zjawisko pogłębiającego się zadłużenia było z powodzeniem wykorzystywane w retoryce politycznej. W kontekście tej retoryki spore wrażenie robi choćby historia Marka

${ }^{2}$ Na podstawie przekazów źródłowych, w tym tekstów literackich, można bez dużego ryzyka przesady pokusić się o sformułowanie wniosku, że nieodpłatność w rzymskiej praktyce to mit, element etosu obywatela, o którym się mówiło, ale w rzeczywistości rzadko wprowadzano w życie. Szeroko o nieodpłatności jako idei, w tym nieodpłatności kontraktu mutuum: J. Michel: Gratuité en droit romain. Bruxelles 1962, zwłaszcza s. 102-127, 596-601; zob. też A. Pikulska-Robaszkiewicz: Lichwa w państwie i prawie republikańskiego Rzymu. Łódź 1999, s. $17-28$.

${ }^{3} \mathrm{O}$ tym ostatnim mówi choćby Liv. 2,23, 5-6; 6, 32, 1.

${ }^{4}$ Pisze o tym wyraźnie Tacyt (Ann. 6,16).

${ }^{5}$ Zob. np. A. Pikulska-Robaszkiewicz: Anatocyzm. W: Profesorowi Janowi Kodrębskiemu in memoriam. Red. A. Pikulska-Robaszkiewicz. Łódź 2000, s. 301-312.

${ }^{6} \mathrm{O}$ surowości tej egzekucji wspomina wielokrotnie Liwiusz (np. Liv. 2, 23, 1-8; 6, 11, 8; $6,143-144 ; 6,34,2)$.

${ }^{7}$ Liwiusz daje nawet wyraz podejrzeniu (w szczeg. Liv. 6,15,7), że patrycjuszowska władza sama prowokowała sąsiadów do wojen po to, by przez pobór do wojska łagodzić problemy wewnętrzne.

${ }^{8}$ A. Pikulska-Radomska: Fiscus non erubescit. $O$ niektórych italskich podatkach rzymskiego pryncypatu. Łódź 2013; zob. też A. Świętoń: s.v. Stipendium. W: Wielka encyklopedia prawa. T. 1: Prawa świata antycznego. Red. B. Sitek, W. Wołodkiewicz. Warszawa 2014, s. $390-391$. 
Manliusza, dostarczająca nie tylko informacji o napięciach społecznych i nastrojach panujących wśród zadłużonych plebejuszy, ale i metodach ich uśmierzania9.

Tak zarysowana problematyka jest dość złożona, tu zostaną przedstawione jedynie niektóre jej aspekty. Dość powiedzieć, że historia większości ustawodawstw, zarówno dawnych, jak i nowożytnych, pokazuje jasno, że praktycznie w każdej epoce dłużnicy żądali od prawodawców ochrony przed nadmiernymi żądaniami wierzycieli udzielających oprocentowanych pożyczek i prawie zawsze żądania te były uwzględniane. Państwo rzymskie, nie tylko w epoce republikańskiej, także interweniowało, i to dwutorowo. $Z$ jednej strony stosowano rozwiązania o charakterze publicznoprawnym, polegające na ustawowej redukcji zadłużenia przy użyciu środków publicznych (tabulae novae ${ }^{10}$ ). $\mathrm{Z}$ drugiej, także w drodze ustawy, usiłowano poskromić chciwość pożyczkodawców przez wprowadzenie ograniczeń swobody w określaniu umawianego stypulacyjnie oprocentowania pożyczek, nakładając przy tym równolegle, choć nie każdorazowo, sankcje na naruszających zakazy. Tabulae novae można w tym opracowaniu zostawić z boku, choć żądania takich aktów pojawiały się w republikańskiej rzeczywistości społecznej bardzo często - zadłużenie przygniatało, bo odsetki były wysokie, a szansa na spłatę niewielka, skoro środki wzięte tytułem pożyczki zostały przejedzone. Zrozumiałe, że hasło oddłużenia w agitacji politycznej musiało trafiać na podatny grunt. Warto tylko zaznaczyć, że interwencje państwa nie miały nic wspólnego z działalnością charytatywną, a regulacje te były okresowo skutecznymi narzędziami utrzymania porządku społecznego.

Wiele argumentów przemawia za tym, że pierwsza regulacja dotycząca odsetek znalazła się w ustawie XII tablic ${ }^{11}$. Abstrahując w tym miejscu od szczegółów sporu toczonego w nauce, wystarczy zaznaczyć, że pierwotna maksymalna stopa odsetek została określona jako fenus unciarium. To $1 / 12$ kapitału, a więc $81 / 3 \%$, naliczane w skali miesiąca, to jest $100 \% \mathrm{w}$ skali roku. Regulacja ta została powtórzona wiek później przez lex Duilia Menenia (358 r. p.n.e.). To wyraźnie nie wystarczało, tym bardziej że oblężenie Wejów i najazd galijski rujnowały zapewne liczne rzesze plebejuszy, skoro w roku 347 p.n.e. na mocy nieznanego z nazwy plebiscytu obniżono dopuszczalne ustawowe stopy procentowe do poziomu semiuncia ${ }^{12}$, tj. 4 1/6\% miesięcznie, a więc 50\% w skali roku. Dalsza radykalizacja nastrojów doprowadziła do przyjęcia skrajnego rozwiązania, tzn. całkowitego zakazu udzielania oprocentowanych pożyczek, wprowadzonego w roku 342 p.n.e. przez lex Genucia $^{13}$. To radykalne rozwiązanie z pewnością

9 Pisze o nim wielu: obszernie Liv. 6, 11-20; poza nim m.in. Diod. 15,35; App. Reb. ital. 9.

${ }^{10}$ Używają tego terminu w tym właśnie znaczeniu np. Cezar (Caes. Civ. 3,1,3), Liwiusz (Liv. 32, 38, 9), Cycero (Cic. Att. 5,21,13); zob. też A. Pikulska-Robaszkiewicz: Lichwa..., s. $29-38$.

11 Tac. Ann. 6,16; Liv. 7,16,1; zob. A. Pikulska-Robaszkiewicz: Lichwa..., s. 39-57.

12 Liv. 7, 27, 3; Tac. Ann. 6,16.

13 Liv. 7, 42, 1; App. Bell. civ. 1,54. 
nie odpowiadało warunkom, w jakich przyszło mu funkcjonować i nawet nie wiadomo dokładnie, jakie sankcje przewidziano dla łamiących zakazy (choć Appian mówi o karach).

Dla tych rozważań istotne jest jednak przede wszystkim udzielenie odpowiedzi na zasadnicze pytanie, czy ustawowych limitów przestrzegano, a jeśli nie, to w jaki sposób je obchodzono. I tu pojawia się nowa, fascynująca płaszczyzna obserwacji.

W narracji Liwiusza dotyczącej połowy IV w. p.n.e. wiele jest wzmianek o lawinowo pogłębiającym się zadłużeniu. To może oznaczać, że unciarium fenus $\mathrm{z}$ ustawy XII tablic nie było przestrzegane, a więc w praktyce pobierano wyższe odsetki. Stąd zapewne ponowienie tej regulacji w lex Duilia Menenia. Choć ustawa ta formalnie nie zmieniła niczego $\mathrm{w}$ dotychczas obowiązującym stanie prawnym, to jednak jej wydanie nie było dla społeczności szokiem - co innego zmieniać regulacje decemwirów, a co innego je obchodzić. Takim szokiem było raczej wydanie plebiscytu o semiuncia, ale po otrząśnięciu się z niego droga do realizacji populistycznych żądań trybunów stała już otworem i całkowicie zabroniono udzielania oprocentowanych pożyczek. Zakaz taki był całkowicie sprzeczny z potrzebami obrotu i warunkami ekonomicznymi, w jakich miał funkcjonować, to jednak nie potrzeby obrotu zdecydowały o jego wprowadzeniu.

Nie zaskakuje więc, że regulację tę spotkał los typowy dla wszystkich praw niedostosowanych do warunków ekonomicznych - wkrótce zaczęto skutecznie obchodzić zawarty w niej zakaz. Przestrzeganie regulacji musiałoby zresztą doprowadzić do całkowitego załamania stosunków kredytowych. Odsetki były więc nadal pobierane, tym bardziej że ustawy te były w najlepszym razie minus quam perfectae, ich naruszenie zatem nie powodowało nieważności stypulacji odsetkowej, nakładając jedynie na naruszającego obowiązek zapłacenia kary. Dodajmy: niemałej. W postępowaniu apud populum wymierzano poena quadrupli, to jest karę w wymiarze czterokrotnej wartości. Czego? Najpewniej nienależnie pobranego świadczenia, choć brak przesłanek do odrzucenia poglądu, że podstawą naliczenia był cały obrót ${ }^{14}$.

W celu obejścia zakazów rzymscy lichwiarze zastosowali prosty sposób polegający na podstawieniu podmiotów ${ }^{15}$. Umowy w ich imieniu zawierali Latyni lub sprzymierzeńcy, których zakaz zawarty w lex Genucia nie obejmował. Jest to kolejny dowód na to, że żywioł społeczny zawsze znajdzie sposób na obejście przepisów niedostosowanych do warunków, w jakich żyje. Upłynęło jednak półtora wieku, zanim w roku 193 p.n.e. uchwalono lex Sempronia de pecunia credita $^{16}$, rozciągającą zastosowanie rzymskich regulacji dotyczących udziela-

${ }^{14}$ Zob. A. Pikulska-Radomska: „...A kiedy pieniędzy publicznych na to nie wystarczato...". Uwagi o karaniu lichwiarstwa w rzymskiej republice. W: Prawo karne i polityka w państwie rzymskim. Red. K. Amielańczyk, A. Dębiński, D. Słapek. Lublin 2015, s. 135-143.

${ }_{15}$ Proceder ten opisuje Liv. 35,7, 2-5.

${ }^{16}$ Liv. 35,7,2-5. 
nia oprocentowanych pożyczek na Latynów i socii. Plebiscytowi temu można by przypisać epokowe znaczenie. $\mathrm{W}$ epoce personalności prawa rozciągnął on zastosowanie norm rzymskiego ius civile na osoby spoza kręgu obywateli. Podkreślić jednak należy, że zastosowanie tego aktu rozciągało się jedynie na stosunki kredytowe między obywatelami i sprzymierzonymi, nie zaś na stosunki sprzymierzonych między sobą, co w tej epoce byłoby możliwe tylko w drodze ich własnej regulacji. Akt ten zobowiązywał wszystkich wierzycieli do złożenia w określonym terminie deklaracji dotyczących pożyczek udzielonych na procent obywatelom rzymskim.

Lex Sempronia w założeniu miała zapewne dać dłużnikom ochronę przed żądaniami nieobywatelskich wierzycieli, ale niewiele wskazuje, by w rzeczywistości odegrała znaczącą rolę. Popadła raczej w zapomnienie, będąc kolejną z licznych, choć nieskutecznych regulacji problemu odsetek. Nieskuteczność tej i innych leges potwierdza dramatycznie opresja, w jakiej znalazł się wiek później pretor M. Semproniusz Asellion, który przypłacił życiem chęć przywrócenia dawnych praw w interesie zadłużonych. Oburzeni lichwiarze zabili go na rynku, nie zdążył nawet dobiec do świątyni, by tam szukać schronienia ${ }^{17}$.

U schyłku republiki sytuacja ekonomiczna i społeczna uległa dość istotnej zmianie. $\mathrm{W}$ tych zmienionych warunkach, wraz $\mathrm{z}$ nasileniem kontaktów handlowych z Grecją i Azją, zmianie uległ także dotychczasowy sposób naliczania odsetek. Społeczeństwo rzymskie tej doby dalekie już było od archaicznej społeczności wieśniaczej, przekształciło się bowiem w zhellenizowane społeczeństwo miejskie, pełne ludzi interesu zajmujących się transakcjami finansowymi. W tych warunkach straciło rację bytu unciarium fenus, które było produktem pożyczek artykułów żywnościowych, funkcjonującym w rytmie prac rolnych. W społeczeństwie, które szeroko otworzyło się na obrót pieniężny, pojawiła się usura jako wynagrodzenie płacone z tytułu korzystania z cudzego kapitału. Centesimae usurae, po raz pierwszy wprowadzone ok. 70 r. p.n.e. dla Azji Mniejszej przez jej namiestnika Lukullusa ${ }^{18}$, wkrótce znalazły powszechne zastosowanie, a oficjalnie zostały ustanowione uchwałą senatu z końca 51 r. p.n.e. ${ }^{19}$. System polegał na naliczaniu setnej części należności głównej miesięcznie, co daje $12 \%$ w stosunku rocznym.

Cycero, który w swoich listach poświęca sporo miejsca sprawom finansowym (sam często bywał $\mathrm{w}$ tarapatach finansowych i korzystał $\mathrm{z}$ pomocy możnych protektorów), opisuje wolny rynek odsetek z ostatnich dziesięcioleci republiki. $\mathrm{W}$ roku 62 mówi o pożyczce udzielonej na semisses, tj. $6 \%{ }^{20}$, pod rokiem 61 wspomina, że fenerator Caecilius (zresztą wuj Attyka) nie może wyciągnąć

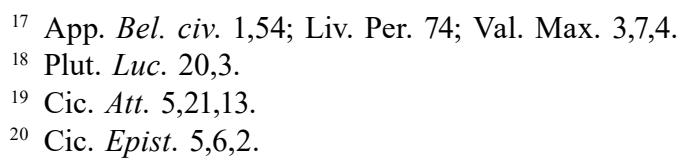


więcej niż $12 \%{ }^{21}$, w roku 54 wreszcie informuje, że w szczytowym okresie kampanii wyborczej oprocentowanie wzrosło z $4 \%$ do $8 \%{ }^{22}$. I myliłby się ten, kto by sądził, że podane wartości naliczane były w stosunku rocznym.

Najwięcej miejsca poświęca Cycero słynnej lichwiarskiej pożyczce Brutusa, z którą zetknął się w 51 roku, kiedy został namiestnikiem prowincji Cylicji ${ }^{23}$. Wkrótce po objęciu stanowiska przyszło mu rozstrzygać spór między obywatelami rzymskimi M. Skaptiusem i P. Martiniusem a przedstawicielami cypryjskiego miasta Salamis. Sprawa zaczęła się w 56 r. p.n.e., niedługo po podboju Cypru i wcieleniu go do prowincji Cylicji. Wtedy właśnie przybyło do Rzymu poselstwo Salamis w nadziei na uzyskanie pokaźnej pożyczki. Posłom udało się zawrzeć umowę z wymienionymi obywatelami, familiarami Brutusa, jednego z późniejszych zabójców Cezara. Pożyczkodawcą był w rzeczywistości sam Brutus. Zastosowano tu zatem zabieg polegający na podstawieniu podmiotów. Pożyczka została oprocentowana w wysokości 4\% w stosunku miesięcznym, a więc $48 \%$ w skali roku. Wystawiono skrypt dłużny, zawarto też dodatkową umowę o doliczaniu do długu skapitalizowanych odsetek. Transakcja doszła do skutku wbrew postanowieniom wydanej rok wcześniej lex Gabinia ${ }^{24}$. Plebiscyt ten, uchwalony na wniosek trybuna Aulusa Gabinusa, zakazywał udzielania w Rzymie pożyczek prowincjuszom i miał na celu poskromienie chciwości zarówno znaczących obywateli, jak i zwykłych lichwiarzy, a w każdym razie, by lichwa nie była uprawiana zbyt jawnie. Postanowienia lex Gabinia zostały w tym przypadku złamane legalnie. Wykorzystując swoje koneksje, Brutus doprowadził do wydania dwóch uchwał senatu, zezwalających zarówno na zawarcie umowy, jak i ustalenie odsetek na wspomnianym poziomie. (Swoją drogą: jeśli Brutus nie krępował się brać $48 \%$ rocznie plus anatocyzm, to ile musieli pobierać zwykli lichwiarze?)

Cycero znalazł się w bardzo niewygodnej sytuacji, sam bowiem był zadłużony u Brutusa (nie tylko zresztą u niego). Żalił się Attykowi ${ }^{25}$, że przed wyjazdem do prowincji otrzymał od Brutusa list, w którym ten prosił o pomyślne rozstrzygnięcie sporu. Wiedział też, że wierzyciele usiłowali odzyskać należność różnymi sposobami - także siłą ${ }^{26}$. $Z$ jednej strony więc nie chciał zrazić do siebie Brutusa, $\mathrm{z}$ drugiej jednak nie chciał łamać postanowień własnego edyktu przewidującego centesimae usurae cum anatocismo anniversario ${ }^{27}$. Salaminianie byli nawet skłonni zapłacić całość, twierdząc, że i tak będą płacić z jego kie-

${ }^{21}$ Cic. Att. 1,12,1, Seneka (Sen. Epist. 118,2) nazywa go nieubłaganym: quam durus sit fenerator Caecilius, a quo minoris centesimos propinqui nummum movere non possit.

${ }^{22}$ Cic. Q. fr. 2,14 (2,15b); ta sama informacja w Cic. Att. 4,15.

${ }^{23}$ Cic. Att. 5,21; 6,1-1.

${ }^{24}$ Cic. Att. 5,21,12.

${ }^{25}$ Cic. Att. 5,21,13.

${ }^{26}$ Cic. Att. 6,1.

27 Cic. Att. 5,21,11. 
szeni, skoro nie przyjął zwyczajowej łapówki. Po licznych próbach osiągnięcia kompromisu. Cycero umył ręce i opuścił prowincję, nie załatwiwszy sprawy.

Koniec republiki to okres bardzo wysokich odsetek pobieranych w praktyce i powszechnie, z naruszeniem, a przynajmniej obejściem prawa, i w atmosferze dezaprobaty społecznej. Ale pobieranych i to powszechnie.

Źródłem inspirującej refleksji może być też spojrzenie na tzw. leges sumptuariae. Bogatym źródłem wiedzy o nich są Noctes Atticae Aullusa Gelliusza $(2,24)$ i Saturnalia Makrobiusza $(3,17)$. To cała duża grupa ustaw mających na celu ograniczanie rozrzutności i nadmiernych wydatków ${ }^{28}$. Lista leges sumptuariae jest dosyć długa, tradycyjnie umieszcza się na niej różnej rangi akty wydawane między 217 a 18 r. p.n.e., choć w rzeczywistości pierwsze takie regulacje pochodzą z okresu królewskiego, a wiele $\mathrm{z}$ nich zawarto $\mathrm{w}$ ustawie XII tablic. Na liście znajdują się zarówno takie akty, przedmiotem których uczyniono wyłącznie kwestię ograniczenia zbytkownych wydatków, jak i takie, które postanowienia limitujące nadmierne wydatki i hojność wprowadzają niejako przy okazji innych postanowień, służących do realizacji nieco odmiennych niż zwalczanie rozrzutności celów społecznych. Tak więc obok regulacji dotyczących stroju i innych zewnętrznych objawów zbytku wprowadzały ograniczenia co do rodzaju i wartości podarków wręczanych zwyczajowo z okazji różnych świąt, regulowały kwestię marnotrawstwa, powracały także kilkakrotnie do problemu kosztów ceremonii pogrzebowych i styp.

${ }^{28}$ Ostatnio o nich: Aulus Gellius: Noctes Atticae 2,24 de vetere parsimonia; deque antiquis legibus sumptuariis - Aulus Gelliusz: Noce Attyckie 2,24 o dawnej oszczędności $i$ o starożytnych ustawach dotyczacych wydatków. Przekł. A.R. Jurewicz, M. Piechocka-Kłos, wstęp M. Piechocka-Kłos, komentarz A.R. Jurewicz. Poznań 2012; zob. też recenzję tej pozycji: M. Kuryłowicz, „Czasopismo Prawno-Historyczne” 2013, T. 65, nr 2, s. 446450; J. Rominkiewicz: O rzymskich ustawach ograniczajacych wydatki na organizację uczt (Makrobiusz, Saturnalia 3,17). „Acta Universitatis Wratislaviensis” No 3741, Prawo CCCXXI. Wrocław 2016, s. 29-55 i literatura tam podana. Dość łatwo dostępna polskojęzyczna dawniejsza literatura to $\mathrm{np}$. J. Sondel: Les 'leges sumptuariae' considérées comme l'expression des conditions sociales et économiques de la Rome antique. „Archivum Iuridicum Cracoviense”, 1973, Vol. 6, s. 101-124; M. Kuryłowicz: Prawo i obyczaje w starożytnym Rzymie. Lublin 1994, s. 43-53; Idem: Leges sumptuariae w państwie i prawie rzymskim. W: Z historii państwa, prawa, miast i Polonii. Prace ofiarowane Prof. Wt. Ćwikowi w czterdziestolecie jego pracy twórczej. Red. J. Ciągwa, T. Opas. „Rzeszowskie Zeszyty Naukowe. Prawo, Ekonomia” 1998, T. 25, s. 139-154; M. Kuryłowicz: Prawo rzymskie wobec przejawów luksusu i marnotrawstwa. W: Zbytek i ubóstwo w starożytności i średniowieczu. Red. L. Kostuch, K. Ryszewska. Kielce 2010, s. 131-140; A. Pikulska-Robaszkiewicz: Ustawowa regulacja obyczajów w prawie rzymskim. „Studia Iuridica” 1999, T. 37, s. 213-219; K. Chytła: Sit modus in rebus - rzecz o ,leges sumptuariae” w prawie rzymskim. „Zeszyty Prawnicze TBSP UJ” 2004, z. 11/12, s. 131-138; A.R. Jurewicz: Czymże jest wolność, jeśli nie wolno temu, kto chce, umrzeć $w$ luksusie? W: Człowiek pomiędzy prawem a ekonomia w procesie integracji europejskiej. Red. G. Dammaco, B. Sitek, O. Cabaj. Olsztyn-Bari 2008, s. 338-342. 
Szczególnie interesującą, także obyczajowo, grupę uregulowań stanowią tzw. leges cibariae, zawierające postanowienia ograniczające nadmierne wydatki i luksus w ucztach i serwowanych na nich potrawach. Określały one szczegółowo dopuszczalną liczbę uczestników biesiad, maksymalne kwoty, które mogły być wydatkowane na zorganizowanie uczty, jak również wagę srebrnej zastawy stołowej, która mogła znaleźć się na stole. Wszystkie te wartości były zróżnicowane $\mathrm{w}$ zależności od okazji, z jakiej uczta była wydawana ${ }^{29}$. Tu ujawnia się interesująca koincydencja między tą grupą ustaw a przeciwdziałaniem korupcji politycznej (crimen ambitus) $)^{30}$. Szczególnym rodzajem nadużycia wyborczego w republikańskim Rzymie była organizacja uczt, rozdawnictwo żywności bądź innych dóbr w związku z ubieganiem się o urząd publiczny. Tego rodzaju praktyki mogły przybierać postać przekupstwa politycznego, czyli largitio. Na szczególną uwagę w tym kontekście zasługują postanowienia lex Antia (między 71 a 68 r. p.n.e.), która miała zapobiegać korumpowaniu urzędników wystawnymi biesiadami i podarkami. Określała ona szczegółowo, czyje zaproszenie urzędnik lub kandydat do urzędu może przyjmować31.

Nie ulega wątpliwości, że ustawy te były powszechnie obchodzone, na przykład lex Fannia wydana w 162, bądź 161 r. p.n.e., o której piszą i Gellisz, i Makrobiusz ${ }^{32}$. Ograniczała ona wartość wydatków, jakie można było ponosić na zorganizowanie uczty zarówno w dni powszednie, jak i świąteczne. Limitowała także liczbę zapraszanych gości. Pliniusz Starszy ${ }^{33}$ podaje dodatkowo, że ustawa zakazywała serwowania potraw z ptactwa, wyjątek stanowiła kura i to nietuczona. Ponieważ ustawa mówiła tylko o kurach, zaczęto specjalnie tuczyć koguty, co podobno prowadziło do uzyskania jeszcze smaczniejszego i delikatniejszego mięsa. Ponieważ przepisy tej ustawy odnosiły się jedynie do Rzymu, zaczęto wystawnie ucztować w podmiejskich posiadłościach. Ciekawe są losy wspomnianej lex Antia. Makrobiusz pisze, że ,ustawę tę, chociaż była znakomita,

${ }^{29} \mathrm{Na}$ marginesie warto zauważyć, że poza reglamentacją wydatków ustawodawstwo to promowało produkcję własną, zakazywano bowiem, a przynajmniej ograniczano podawanie zagranicznych win, ziół i innych delikatesów pochodzących spoza Italii. Choć tak naprawdę chodziło o zatrzymanie kruszców w Italii.

${ }^{30}$ Problematyka crimen ambitus ma bogatą bibliografię; w literaturze polskiej ostatnio pisali o nich m.in. A. Zandberg: Leges de ambitu. Rzymskie ustawodawstwo wyborcze u schytku republiki. „Meander” 2001, nr 1-2, s. 103-126; M. Sobczyk: Przestepstwo korupcji wyborczej w republikańskim Rzymie. „Czasopismo Prawno-Historyczne” 2014, Vol. 66, z. 2, s. 11-30; zob. też literaturę tam podaną; w kontekście lex lulia coloniae Gentivae seu Ursonenis niedawno pisał o nich B. Sitek: Convivium, cena i donum munus $w$ antycznym Rzymie a wspótczesne dylematy korupcji wyborczej (crimen ambitus). „Studia Prawnoustrojowe” 2010, T. 11, s. 5-15; zob. też K. A mielańczyk: s.v. Ambitus. W: Wielka encyklopedia prawa. T. $1 \ldots$, s. 94.

${ }^{31}$ Gell. NA 2,24,13; Macr. Sat. 3,17,13.

${ }^{32}$ Gell. NA, 2,24,3; Macr. Sat. 3,17,3-5; są też wzmianki u innych autorów, więcej w szczególności J. Rominkiewicz: $O$ rzymskich..., s. 44-45.

33 Plin. NH. 9,139. 
stałość luksusu i silne przyzwolenie na błędy uczyniły bezskuteczną, mimo że nie została uchylona" ${ }^{34}$, a o jej wnioskodawcy — Gajuszu Antiusie Restionie mówiono, że do końca życia jadał w domu, żeby nie widzieć, jak wszyscy łamią zawarte w niej ograniczenia.

Dla oceny ustaw przeciwko nadmiernym wydatkom duże znaczenie ma ustalenie skutków nieprzestrzegania ich postanowień. O tych sankcjach nie wiadomo zbyt wiele. Wydaje się, że na ogół były to leges imperfectae, a wyjątkiem, być może jedynym, była lex Didia (143 r. p.n.e.), która, rozciągając zastosowanie wspomnianej już ustawy Fannia na całą Italię, zawierała postanowienie, że karom, choć nie wiadomo dokładnie jakim, podlegali nie tylko wydający uczty, ale i goście ${ }^{35}$. Wiadomo również, że obywatele rzymscy w zakresie przestrzegania dobrych obyczajów podlegali kontroli cenzorów; ci, którzy te obyczaje łamali, podlegali karom w postaci not cenzorskich, które mogły wywoływać znaczące skutki zarówno w sferze prawa prywatnego, jak i publicznego. Wątpliwości nie budzi też nadzór edylów i stosowanie przez nich środków karno-administracyjnych, $\mathrm{z}$ niszczeniem zakazanych towarów włącznie. Konsekwentnie na straży przestrzegania leges sumptuariae stał Cezar, autor kolejnej ustawy ograniczającej zbytek w ucztowaniu (lex Iulia sumptuaria z 46 r. p.n.e.). Ustawił on na rynku strażników, którzy zabierali zakazane produkty. Większość jednak z tych regulacji to leges programowo imperfectae, a stosowane środki przymusu miały często charakter pokazowy. To ostatnie zresztą można powiedzieć i o publicznych procesach przeciwko lichwiarzom.

Problem ustawodawstwa ograniczającego zbytek ma wątek uboczny w postaci leges aleariae, a więc środków prawnych podjętych w celu poskromienia plagi, jaką był hazard. O ile zbytek i nadmierna hojność były przypadłościami dotykającymi i uprawianymi przez wyższe warstwy społeczeństwa, a niższe mogły najwyżej razić, o tyle hazard był plagą obejmującą całe społeczeństwo, nie wyłączając niewolników. Szczególnie rozpowszechniony był w dołach społecznych, co w połączeniu z faktem, że zwykle był uprawiany w miejscach złej reputacji, knajpach, lupanarach itp., sprawiało, że stanowił zjawisko społecznie niebezpieczne ${ }^{36}$.

${ }^{34}$ J. Rominkiewicz: $O$ rzymskich..., s. 36.

${ }_{35}$ Macr. Sat. 3,17,6.

${ }^{36}$ Pisał o tym wielokrotnie M. Kuryłowicz: Die Glücksspiele und das römische Recht. In: Studi in onore di Cesare Sanfilippo, IV. Milano 1983, s. 369-382; Idem: Alea i kontrakty aleatoryjne $w$ prawie rzymskim. „Czasopismo Prawno-Historyczne” 1984, z. 2, s. 75-90; Idem: Prawo i obyczaje..., s. 81-89; Idem: Das Glückspiel im römischen Recht. „Zeitschrift der Savigny-Stiftung für Rechtsgeschichte. Romanistische Abteilung“ 1985, Bd. 102, s. 185219; Idem: Leges aleariae und leges sumptuariae im antiken Rom. In: Studia in honorem Elemér Polay septuagenarii. Ed. Ö. Both. Szeged 1985, s. 271-279; M. Kuryłowicz: Loca aedilem metuentia (Sen. De vita beata 7, 1, 3). Z działalności edylów rzymskich na rzecz ochrony porządku i moralności publicznej. „Annales Universitatis Mariae Curie-Skłodowska”, Sectio G (Ius) 1988, Vol. 32/33, s. 123-135. 
Wiadomo o trzech republikańskich ustawach zakazujących gier hazardowych. Pochodzą one najprawdopodobniej z II i I w. p.n.e. Podobnie jak leges sumptuariae wyrastały one $\mathrm{z}$ dążności arystokracji rzymskiej do utrzymania tradycyjnych obyczajów i kierowały się przeciwko hazardowi jako nieobyczajnemu występkowi połączonemu z rozrzutnością i marnotrawstwem. Zakazy dotyczące gier hazardowych były konsekwentnie ponawiane, nowej regulacji dokonał też Justynian. Tu istniało jednak zagrożenie karą - była to grzywna w poczwórnej wysokości (czego? Nie wiadomo). Zakazy były ciągle ponawiane, co nie świadczy najlepiej o ich skuteczności, choć, z drugiej strony, w dawnych ustawodawstwach takie ,przypominanie” było powszechnie przyjęte i sprzyjało rozpowszechnianiu wiedzy o regulacjach prawnych.

Przedstawiona wyżej pokrótce historia ustawodawstwa przeciwko lichwie, zbytkowi i grom hazardowym pokazuje jasno, że wspomniane akty wykazywały wyjątkowo małą skuteczność. Wydawane były w szlachetnych intencjach szeroko rozumianej poprawy obyczajów i powstrzymania negatywnego zjawiska zanikania cech dawnego etosu. Były wyrazem szlachetnej, ale nieco naiwnej wiary prezentowanej przez rzymskiego prawodawcę, że wystarczy jakiś problem uregulować ustawą, by móc uznać go za załatwiony. Ta wiara wielokrotnie doznawała wstrząsów, a realia funkcjonowania tych regulacji są kolejnym dowodem na to, że żywioł społeczny zawsze znajdzie sposób na obejście przepisów niedostosowanych do warunków, w jakich żyje.

\section{Bibliografia}

Amielańczyk K.: s.v. Ambitus. W: B. Sitek, W. Wołodkiewicz: Wielka encyklopedia prawa. T. 1: Prawa świata antycznego. Red. B. Sitek, W. Wołodkiewicz. Warszawa 2014.

Aulus Gellius: Noctes Atticae 2,24 de vetere parsimonia; deque antiquis legibus sumptuariis - Aulus Gelliusz: Noce Attyckie 2,24 o dawnej oszczędności $i$ o starożytnych ustawach dotyczacych wydatków. Przekł. A.R. Jurewicz, M. Piechocka-Kłos, wstęp: M. Piechocka-Kłos, komentarz A.R. Jurewicz. Poznań 2012. [Rec. M. Kuryłowicz, „Czasopismo Prawno-Historyczne” 2013, T. 65 , nr 2].

Chytła K.: Sit modus in rebus - rzecz o "leges sumptuariae” w prawie rzymskim. „Zeszyty Prawnicze TBSP UJ” 2004, z. 11/12.

Jurewicz A.R.: Czymże jest wolność, jeśli nie wolno temu, kto chce, umrzeć w luksusie? W: Cztowiek pomiędzy prawem a ekonomiq w procesie integracji europejskiej. Red. G. Dammaco, B. Sitek, O. Cabaj. Olsztyn-Bari 2008.

Kuryłowicz M.: Alea i kontrakty aleatoryjne w prawie rzymskim. „Czasopismo Prawno-Historyczne" 1984, z. 2. 
Kuryłowicz M.: Das Glückspiel im römischen Recht. „Zeitschrift der Savigny-Stiftung für Rechtsgeschichte: Romanistische Abteilung" 1985, T. 102.

Kuryłowicz M.: Die Glücksspiele und das römische Recht. In: Studi in onore di Cesare Sanfilippo, IV. Milano 1983.

Kuryłowicz M.: Leges aleariae und leges sumptuariae im antiken Rom. In: Studia in honorem Elemér Polay septuagenarii. Ed. Ö. Both. Szeged 1985.

Kuryłowicz M.: Leges sumptuariae $w$ państwie $i$ prawie rzymskim. W: $Z$ historii państwa, prawa, miast i Polonii. Prace ofiarowane Prof. Wt. Ćwikowi w czterdziestolecie jego pracy twórczej. Red. J. Ciągwa, T. Opas. „Rzeszowskie Zeszyty Naukowe. Prawo, Ekonomia" 1998, T. 25.

Kuryłowicz M.: Loca aedilem metuentia (Sen. De vita beata 7, 1, 3). Z działalności edylów rzymskich na rzecz ochrony porzadku i moralności publicznej. „Annales Universitatis Mariae Curie-Skłodowska" Sectio G (Ius), 1988, T. 32/33.

Kuryłowicz M.: Prawo i obyczaje w starożytnym Rzymie. Lublin 1984.

Kuryłowicz M.: Prawo rzymskie wobec przejawów luksusu i marnotrawstwa. W: Zbytek i ubóstwo w starożytności i średniowieczu. Red. L. Kostuch, K. Ryszewska. Kielce 2010.

Michel J.: Gratuité en droit romain. Bruxelles 1962.

Pikulska-Radomska A.: ,...A kiedy pieniędzy publicznych na to nie wystarczało...”. Uwagi o karaniu lichwiarstwa w rzymskiej republice. W: Prawo karne i polityka w państwie rzymskim. Red. K. Amielańczyk, A. Dębiński, D. Słapek. Lublin 2015.

Pikulska-Radomska A.: Fiscus non erubescit. O niektórych italskich podatkach rzymskiego pryncypatu. Łódź 2013.

Pikulska-Robaszkiewicz A.: Anatocyzm. W: Profesorowi Janowi Kodrębskiemu in memoriam. Red. A. Pikulska-Robaszkiewicz. Łódź 2000.

Pikulska-Robaszkiewicz A.: Lichwa w państwie i prawie republikańskiego Rzymu. Łódź 1999.

Pikulska-Robaszkiewicz A.: Ustawowa regulacja obyczajów w prawie rzymskim. „Studia Iuridica” 1999, T. 37.

Rominkiewicz J.: O rzymskich ustawach ograniczajacych wydatki na organizacje uczt (Makrobiusz, Saturnalia 3,17). „Acta Universitatis Wratislaviensis” No 3741, Prawo CCCXXI. Wrocław 2016.

Sitek B.: Convivium, cena $i$ donum munus $w$ antycznym Rzymie a współczesne dylematy korupcji wyborczej (crimen ambitus). „Studia Prawnoustrojowe” 2010, T. 11.

Sobczyk M.: Przestepstwo korupcji wyborczej w republikańskim Rzymie. „Czasopismo Prawno-Historyczne" 2014, Vol. 66, z. 2.

Sondel J.: Les 'leges sumptuariae' considérées comme l'expression des conditions sociales et économiques de la Rome antique. „Archivum Iuridicum Cracoviense” 1973. Vol. 6.

Świętoń A.: s.v. Stipendium. W: Wielka encyklopedia prawa. T. 1: Prawa świata antycznego. Red. B. Sitek, W. Wołodkiewicz. Warszawa 2014.

Zandberg A.: Leges de ambitu. Rzymskie ustawodawstwo wyborcze u schylku republiki. „Meander” 2001, nr 1-2. 
Anna Pikulska-Radomska

\section{Ist das Gesetz für alles gut?}

Schlüsselwörter: antikes Rom, Wucher, leges sumptuariae, leges cibariae, politische Korruption

Zusammenfassung: Die römische Republik hatte mit vielen Pathologien zu kämpfen. Dazu gehörten Wucher, übermäßige Verschwendung, Unmäßigkeit beim Essen und Trinken, Glücksspiele oder auch politische Korruption. Diese Erscheinungen hatten weitreichende negative soziale Auswirkungen, und der Staat versuchte sie durch Gesetze zu beseitigen. Ihre Geschichte zeigt deutlich, dass sie einen extrem niedrigen Wirkungsgrad aufwiesen. Sie wurden mit der edlen Absicht verabschiedet, die Sittlichkeit im weiten Sinne zu verbessern und das negative Phänomen des Verschwindens der Merkmale des alten Ethos zu stoppen. Sie waren ein Ausdruck des edlen, aber leicht naiven Glaubens des römischen Gesetzgebers, dass es ausreicht, ein Problem gesetzlich zu regeln, um es als geregelt betrachten zu können. Dieser Glaube wurde mehrmals erschüttert, und die Realität dieser Regelungen ist ein weiterer Beweis dafür, dass das soziale Element immer einen Weg finden wird, Vorschriften zu umgehen, die nicht an die Bedingungen angepasst sind, unter denen es lebt.

Anna Pikulska-Radomska

\section{Is law good for everything?}

Keywords: ancient Rome, usury, leges sumptuariae, leges cibariae, political corruption

Summary: The Roman Republic struggled with many pathologies. These included usury, excessive profligacy, excesses in food and drink, gambling and political corruption. These phenomena caused far-reaching negative social consequences, so the state tried to eliminate them by means of laws. Their history clearly shows that they were extremely ineffective. They were published with noble intentions of improving customs in a broad sense and stopping the negative phenomenon of the disappearance of the features of the former ethos. They were an expression of the noble but somewhat naive faith presented by the Roman legislator that a problem could be solved by means of a law. This faith was shaken many times, and the reality of the functioning of these regulations proves that the society will always find a way to circumvent regulations that are not adapted to the conditions in which it lives. 